\title{
Algological Investigations in Mammoth Cave, Kentucky
}

\author{
By H. J. Jones $\left.\left.{ }^{1}\right)^{2}\right)$
}

With plate 104 (1) and one figure in the text

\section{Introduction}

Biospeleology in the United States is still in its early descriptive period and though the situation has greatly improved since 1931 when Bolivar and Jeannel could make the following statement: "... les naturalistes americaines n'ont enterpris aucune etude serieuse de la faune de l'immense domaine souterraine qui s'offre a leurs investigations. On chercherait en vain dans les collections des Musees un seul cavernicole dont la capture date du $\mathrm{XX}^{\mathrm{e}}$ siecle!," still not a single article deals with American cave floras exclusively.

Scientific inquiry into the microbiological-botanical investigations of the flora of the closed ecological system of caves has been given scant attention especially in comparison with the zoological works conducted in these subterranean habitats. This statement especially holds true for the cavernicole plants of the caves of the United States. Such studies had been initiated already at the end of the last century in European caves and even in America in the early work of Call (1897) 15 fungi are enumerated which were identified from Mammoth Cave in Kentucky. However, due probably to Call's interpretation that all of these fungi are accidental inhabitants of the cave, their presence possibly did not give rise to any special interest which would have furthered the continuation of similar investigations. It is by now an established fact that algae do occur in the total darkness of caves, often in considerable quantities, and it therefore seemed necessary to conduct algalogical investigations into one of the largest caves on the North American continent, the Mammoth Cave of Kentucky. The algal flora of this cave differs considerably from those found in caves

1) Biological Institute, Matthew Maury Research Center, Long Island, N.Y. Present Address: 1504 Hilltop Drive, Tallahassee, Florida.

$\left.{ }^{2}\right)$ This paper represents a portion of a thesis submitted to The Free Protestant Episcopal University, England, in partial fulfillment of the requirements for a Doctor of Philosophy degree in Microbiology. 
on the European continent, and a comparison between these geographically isolated habitats will be discussed.

Very few metazoans and only a limited number of microorganisms have been able to adapt to an eternally lightless environment in which food must be either manufactured in situ by chemosynthetic autotrophs or carried in from the outside. Deep caves provide an essentially isolated thermal environment, in which the most important limiting factors are light, food and vapor pressure deficit.

Caves have received slight attention in the past partially due to the fact that no economic use has been expected from them and also because they are extremely difficult to study. Even the genesis of the limestone cave is obscure. Complications in the biological research of United States caves are due to a lack of prior taxonomic work and also to the physical problems encountered in their investigation. Instruments must be lightweight, portable and shock-resistant. Cavernicoles are exceptionally sensitive to even slight changes in environmental factors (temperature, vapor pressure deficit, light, rate of flow of air and water, dissolved oxygen, etc.). Therefore, control of studies of organisms taken from the caves is difficult to achieve. Although no laboratories for cave research have been built in the United States, there exist a number of these laboratories in Europe. They vary considerably in size and scope of scientific investigation, and are found all over Europe, the most extensive investigations having been carried out in Hungary, France and Romania. The establishment of such cave laboratories in the United States would partially alleviate these problems, but as yet no adequate facilities are available in this country in spite of the concentrated efforts and pleas of enthusiastic workers of the Cave Research Foundation in Washington, D.C.

The most extensive cavern systems in the world lie beneath the Central Kentucky Karst in south central Kentucky about 100 miles south of Louisville, in the Flint Ridge, Mammoth Cave Ridge, and Joppa Ridge systems. Over 28 miles of passages have been surveyed in Mammoth Cave itself, and nearly 35 miles have been surveyed in the larger Flint Ridge system to the North. Several large caves and hundreds of smaller caves are known within the Mammoth Cave plateau and adjacent Pennyroyal plateau. All of them are excavated in the Mississippian limestones of Chester and Meramac age, especially the fine-grained and often oölitic Ste. Geneviève and Girken (Renault Paint Creek) limestones, which in some places reach an exposed thickness of as much as 300 feet. These limestones lie under a thick (110 feet) layer of Big Clifty (Cypress) Sandstone. This sandstone forms the caprock of the Mammoth Cave Plateau and is overlain by the Haney 
(Golconda) limestone, which includes many thin shale beds throughout its maximum 40 foot thickness. These formations dip towards the Northwest at approximately 30 feet per mile toward the Green River, into which most of the underground water in these cave systems eventually emerge.

Surface erosion is inhibited by the resistant sandstone caprock, accounting for the extensiveness of the massive horizontal interconnected caverns below. The impermeable shale layers in the thinner limestone overlying the sandstone divert underground water to the edges of the ridges where the caprock has been removed, there seeping down to eventually form the vertical shafts. The slow surface erosion continues to preserve the massive cave system. (See Text Figure 1.)

Both physical factors and food supply vary considerably from one season to another. The Echo and Styx rivers in Mammoth Cave rise 6 to 15 meters during the winter or spring flood season above the low autumn level. Great variety in $\mathrm{pH}$, total alkalinity, dissolved oxygen and plankton density is observed on a seasonal basis. Streams sinking on the Pennyroyal plateau 10 to 18 miles from Mammoth Cave form these two rivers. During the winter and spring the Green River waters also back up into the cave, intensifying flood conditions. In Mammoth Cave's Crystal Lake, fed by seeping rather than running waters, physical changes are less and occur more regularly. The average an-
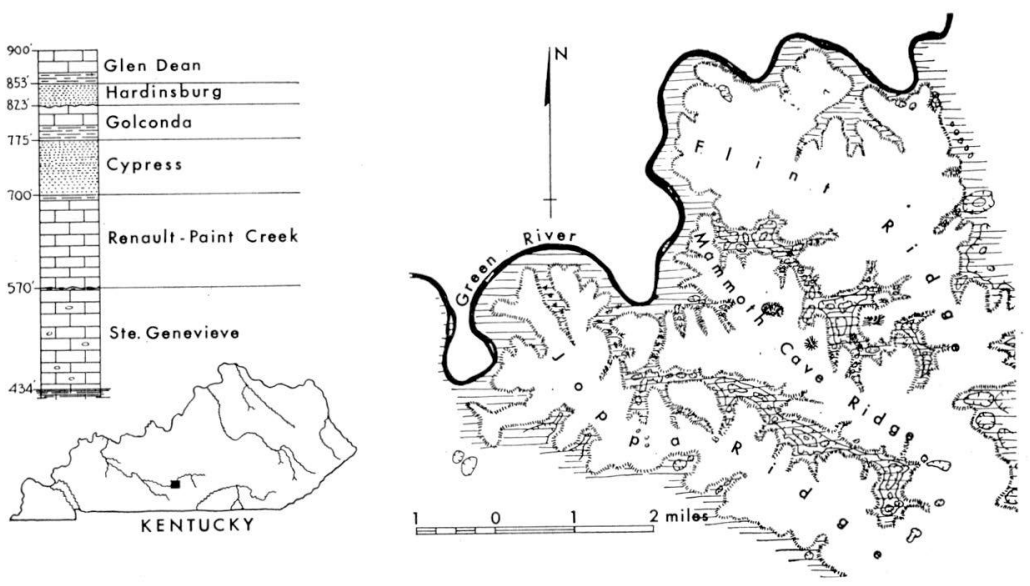

Fig. 1. The Kentucky Karst System with the three main ridges containing the caves. On the left side of the figure is the columnar section of the Mississippian formations after J. M. WeLLER. (Drawing published with the permission of Cave Research Foundation.) 
nual rainfall for this region is from 45 to 50 inches (Benington et al., 1962; Lobeck, 1929; Smith, 1964; Watson and Smith, 1963).

While the existence of these caves has been known since before the 15th century, B.C., extensive exploration did not begin until the late 19 th and early 20th centuries. The early explorers were interested only in developing the caves for commercial and tourist purposes. While the extraordinary opportunities for biospeleological research in the Kentucky cave region have long been recognized, it is only within the past few decades that any attempt has been made to begin these studies (Barr, 1962; Barr, 1964; etc.). Only an estimated 50 percent of the cavernicoles of the United States are known, thus complicating or at least delaying ecological research in many other cave systems. A great impetus to the further development of cave research in this country was supplied by the establishment of a special Institute for Speleology at the University of Lexington, Kentucky, under the direction of Dr. Thomas C. Barr, Jr. in 1963.

\section{Materials and Methods}

In the summer of 1963 we received 13 vials of living algae collected by G. Claus in the Mammoth Cave of Kentucky for identification. At this place I wish to express my sincere gratitude to Dr. George Claus for letting me investigate this interesting material. The diatom flora of the cave is not included in the present work and will be reported elsewhere.

According to the personal communication of Claus the collections were made in the following way: scrapings from the walls of the cave, from logs, from the speleo-clay of the floor of the cave and from the stalactites and stalagmites were made with flame sterilized instruments and were placed in sterile vials. Additional materials, if visibly large colonies were present, were secured by forceps or spoons. Sediment from the small ponds of the cave was collected by a spoon while young stalactites were chipped off with pliers. All of the appliances used were autoclaved.

According to the attached list the descriptions of the samples and their localities in the cave are as follows:

No. 1. Dark bluish-green covering on rocks. Richardson Spring.

No. 2. Small, blackish patches on rocks and stalactites. Minerva's Dam.

No. 3. Darkish veins on small stalactites. Darnall's Way.

No. 4. Tufts of blackish red, mucinous material on old logs. Washington's Pit Bridge. 
No. 5. Scrapings from speleo-clay and from the walls. Natural bridge at Styx River.

No. 6. Mud from small ponds. Second Landing River.

No. 7. Scrapings from greenish discoloration on walls. Lorrain River Passage.

No. 8. Abundant bluish-grey, mucous growth on rock walls. Mammoth Tower.

No. 9. Yellowish-white, mucous growth on rotting rug. Crevacea Pit.

No. 10. Mud from small ponds. Corridor after Mammoth Tower.

No. 11. Wall Scraping of blackish, layered, corrugated material. Main corridor.

No. 12. Heavy bluish-green growth on walls around a lamp. Main Corridor.

No. 12a. Branching red growth on old log. Main Corridor.

After their arrival to our laboratories the contents of the vials were divided into three portions, two of which were aseptically transferred into $300 \mathrm{ml}$. Erlenmeyer flasks filled with either soil water, or with Chu No. 10 media as recommended by Starr (1960). From the third portion of the material microscopic slides were prepared and investigated for the occurrence of algae prior to culturing. In the systematic part it is specifically mentioned whether or not a form was found prior to or only after culturing.

The flasks after inoculation were placed in a culture chamber having a constant $16^{\circ} \mathrm{C}$. temperature and an illumination for each flask of approximately 2000 lux for 18 hours each day.

After ten weeks of incubation, when the majority of the flasks showed well developed algal growth the identifications were carried out. After opening the flasks, however, subcultures were prepared from each of them in the same kind of media used previously. The subcultures were grown again for ten weeks and were identified again. No species was found in any of them which did not occur in the first series of identifications. From the algae grown in the subcultures exiccata were prepared.

For the identification work a Leitz Ortholux microscope with $40 \times$, $63 \times, 70 \times$, and $93 \times$ phase objectives and with $12 \times$ and $25 \times$ oculars was used. The drawings were prepared from projections of selected specimens.

\section{SYSTEMATIC PART}

After the name of the species their usual occurrences are given, taken over from the commonly used identification guides. 


\section{CYANOPHYTA}

\section{Chroococcaceae}

\section{MICROCYSTIS STAGNALIS Lemm.}

Planktonic in still water. The occurrence of this form in the cave is surprising especially in view of the fact that the alga was found growing on the moist wall and did not originate from the small ponds abundant in the cave. Both according to its typical colony morphology and the measurements of the single cells there can be but little doubt as to the identity of the species, hence one has to conclude that this planktonic form is able to vegetate to a certain degree under aerial conditions (Sample No.6).

\section{Gomontiellaceae}

\section{GOMONTIELLA MAGYARIANA Claus}

Filaments up to $240 \mu$ long, solitary, erect, brownish-green; along the septa considerably constricted; "inrolled" to form a tube, 9-10 $\mu$ wide, in cross section elliptical, with equally long $(2.5 \mu)$ bent back borders. Cells $2 \mu$ long with edges bent together with a distance of at least $2.5 \mu$ between them, if spread out 6-7 times shorter than wide. Figs. $1 \mathrm{a}-1 \mathrm{~b}$.

Since the description above is in almost complete agreement with that provided by Claus (1960) there is no doubt as to the identity of the species, in spite of the fact that in my material I could not observe the longitudinal division of the cells; furthermore the cells of the specimens did not pull apart to form a zig-zag as depicted by Claus (loc. cit., fig. 10) in his form. Further support as to the identity of the two forms can be derived from the fact that the species described by Claus was also found in a subterranean habitat, in the Cave of Kölyuk in Hungary. Although the distance between the two known localities is rather great, which should have given rise to an effective geographical isolation - a species forming factor - the almost ubiquitous occurrence, the great ecological valency, the easy transportability of the blue-green algae, and the lack of known sexual processes occurring among them - a factor working against speciation - may account for the finding of the same species in two different continents. Furthermore, since the algal floras of the caves of either Europe or America are almost completely unknown it is quite plausible that the above described species will be found in many other caves, both in Europe and America, which certainly will decrease the, at the present time, 
seemingly unbridgeable geographical distance between the two described localities. Found also in the original material without culturing (Sample No. 12).

\section{Nostocaceae}

\section{NOSTOC MINITISSIMUM Kütz. emend. Claus}

Microscopically small thalli, spherical, with a firm yellowish-brown capsule on the periphery. Filaments loosely congested, at the crosswalls markedly constricted, $1.3-1.7 \mu$ wide, olive-green. Sheaths confluent, no staining with chlorzinc-iodine. Cells quadrate or barrelshaped, about 1-1.5 times longer than wide, usually $1.5-2.0 \mu$ long. Protoplasm clearly divided into a chromatoplasm containing fine granules and a faint, homogenous centroplasm. Heterocysts more or less spherical, with diameter of $2-8 \mu$. Arthrospores $3.5 \mu$ wide, $5.6 \mu$ long, with smooth, brown walls. The description given above undoubtedly aligns the form to N.minutissimum as emended by Claus (1961). The species seem to be cosmopolitan and occurs both in aqueous and aerial environments (Sample No. 1).

\section{Oscillatoriaceae}

4. OSCILLATORIA SUBTILISSIMA Kütz.

In still water, in the sapropel. Found also in the original material sample No. 11 - without culturing (Sample Nos. 7, 11).

\section{OSCILLATORIA NEGLECTA Lemm.}

On damp walls, lakes, often in mud, most probably ubiquitous (Sample No. 8).

\section{OSCILLATORIA ANIMALIS Ag.}

Ubiquitous, cosmopolitan. Found also in the original sample without culturing (Sample No. 12).

\section{OSCILLATORIA CLAUSIANA ${ }^{3}$ ) spec. nov.}

Trichomata solitaria, erecta, ad apices non attenuata sed capitata, ad septa non constricta, 1.6-1.8 $\mu$ lata; cellulis curtioribus quam latis, 0.7-1.0 $\mu$ latis; cellulis apicalis capitatis. Protoplasma homogenea, pallide coerulea,

3) The species was named in honor of its collector, Dr. G. Claus. 
sine differentiatione chromatoplasmateque centroplasmate et sine granulis; motatione cunctando. A O. kuetzingiana Naeg. mensuris parvisque cellula apicali capitata differt.

Typus: O. clausiana spec. nov. in herbaria Rijksmuseatis Stockholmiensis deposita.

Iconotypus: II. figura nostra.

Trichoms solitary, \pm erect, not tapering towards the end and not constricted at the crosswalls, 1.6-1.8 $\mu$ wide; cells shorter than wide, $0.7-1.0 \mu$ long, end cell capitate. Protoplasm homogenous, pale bluishgreen, without visible differentiation into centro- and chromatoplasm and without granules. Motion slow. From O.kuetzingiana Naeg. it differs with its smaller measurements and with its capitate end (Sample No. 10). Fig. 2.

Type species $O$.clausiana spec. nov., dried sample being deposited in the herbarium of the Rijksmuseat in Stockholm.

Iconotype: Fig. 2.

\section{PHORMIDIUM SUBTRUNCATUM Woronich. fa.}

Filaments entangled in a confluent sheath. The mass of the mucous material is quite substantial and is heavily inhabited by bacteria, it became actually impossible to decide whether the Phormidium species penetrate the mucous thallus of a bacterium or the bacteria grow in the confluent sheath of the blue-green alga. Since several Phormidia are known to live in the mucine of other plants the former supposition is probably correct. Trichomes at the cross walls not constricted, $2.0-2.2 \mu$ wide, not tapering towards the ends but bluntly rounded off, no coloration with chlorzinc-iodine; cells shorter than wide, 1.4$1.6 \mu$ long, end cell rounded. Protoplasm pale bluish-green, without visible differentiation into chromato- and centroplasm; granules absent. It differs from the type by its peculiar habitat. Type originally found in streams of Nord Ural, since then it was, however, reported from a variety of different localities throughout Europe; most probably cosmopolitan (Sample No. 1). Fig. 3.

\section{PHORMIDIUM CEBENNENSE Gom.}

On rocks washed by water (Sample Nos. 1, 5).

\section{LYNGBYA PUSILLA Kütz. fa. TENUIOR fa. nov.}

Filamenta solitaria, ad substratum adherentia, erecta, $0.8 \mu$ lata; vagina tenui, firma, non lamellata, chlorocincici-iodurato non colorata; trichomata 0.6-0.7 $\mu$ lata, ad septa non constricta; cellulis quadratis, $0.6-0.7 \mu$ longis, 
cellulis apicalibus obtuse rotundatis; protoplasmate pallide coerulea sine differentiatione chromatoplasmateque centroplasmate et sine granulis. Sessilis in hyphis fungi. A typo suis mensuris parvis differt. Figura: IV. nostra.

Filaments solitary, attached at one end, erect, $0.8 \mu$ wide; sheath thin, firm, unlayered, no coloration with chlorzinc-iodine. Trichoms $0.6-0.7 \mu$ wide, at the crosswalls not constricted and not tapering towards the ends but rounded; cells quadrate, $0.6-0.7 \mu$ long, end cell bluntly rounded; protoplasm pale bluish-green, no differentiation into chromato- and centroplasm, without granules. It differs from the type by its smaller measurements. Sessile on fungus hypha. The type is a cosmopolitan epiphyte (Sample No. 2). Fig. 4.

\section{Beggiatoaceae}

11. BEGGIATOA ALBA (Vauch.) Trev.

In lack of adequate determination of the nutritional requirements of the form found in the cave (cf. Pringsheim, 1964) the species is enumerated under the above name based solely on the measurements of the trichome. On mud, in stagnant or flowing water, cosmopolitan (Sample No. 12).

\section{APPENDIX}

\section{Chlorobacteriaceae}

12. TETRACHLORIS INCONSTANS Pasher

On putrescent mud, in stagnant and flowing water (Sample No. 12).

\section{EUGLENOPHY'TA}

\section{Euglenaceae}

13. TRACHELOMONAS VERRUCOSA Stokes

In the plankton of small ponds, cosmopolitan. Found also in the original sample without culturing (Sample No. 10). 


\section{PHACUS PLEURONECTES (Ehr.) Duj. var. HYALINUS} Klebs

Tychoplanktic on mud of lakes (Sample No. 10).

\section{CHRYSOPHYTA}

\section{Chromulinaceae}

15. CHRYSOCOCCUS KLEBSIANUS Pasch.

In plankton of still water. Found also in the original sample without culturing (Sample No. 12).

\section{APPENDIX}

\section{CHR YSOPHYTA cyst.}

Ellipsoidal bodies with length of $9-12 \mu$, including neck, and width of $6.5-7.5 \mu$; collar funnel shaped, $0.5 \mu$ in diameter and $0.8-1.0 \mu$ in height; wall approximately $0.5 \mu$ thick, spines and protuberances $0.2-0.3 \mu$ long; protuberances and spines scattered. The form is undoubtedly identical to Cyst Type 26 of VanLandingham (1964) which was found in the Yakima Basalt - a Miocene formation in South-central Washington State - and whose affinities are unknown. As no living specimens occurred in the sample to which these cysts could have been attributed their systematic position remains unsolved. Found also in the original material without culture (Sample No. 8). Fig. 5.

\section{CHLOROPHYTA}

\section{Palmellaceae}

17. ASTEROCOCCUS SUPERBUS (Cienk.) Scherf.

On washed rocks in rivers, or in plankton (Sample Nos. 5, 6).

\section{Coccomyxaceae}

18. COCCOMYXA DISPAR Schmidle

Either in plankton or free-living as an aerial epiphyte (Sample No.9).

\section{PLANOPHILA LAETEVIRENS Gerneck}

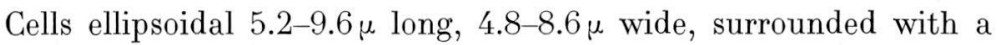
mucous capsule with one parietal chloroplast containing a well devel- 
oped pyrenoid. Propagation either with vegetative division or with biflagellated zoospores; zoospores up to $5.0 \mu$ in length and $3.2 \mu$ in width. Figs. 6 a-6c. The species has not yet definitely reported since the original description of Gerneck (1907) from a moor in Germany. Thus, its occurrence in the Mammoth Cave represents a new report for the United States.

The systematic position of the genus is debated. Most authors agree that Planophila is closely allied to Chlorosarcina or Chlorosphaera, but considerable discrepancy exists among the opinions as to whether or not these genera belong to the Tetrasporales or Chlorococcales and to which family of the mentioned orders. Brunthaler (in Lemmermann et al., 1915) classifies Planophila in the Chlorosphaeraceae family together with Chlorosarcina and Chlorosphaera, under the Tetrasporales. However, Smith (1950), although he does not treat Planophila in his monograph, as this species has not yet been found in the United States, points out that forms like Chlorosarcina (loc. cit., p. 131): "cannot be considered typical Tetrasporales since their cells do not have the capacity to metamorphose directly into a motile condition... There is the alternative of placing them in a group called 'unicellular Chlorophyceae of uncertain systematic position' (as proposed by Pascher, in Lemmermann et al., 1915) but this does not show that there are distinct, though somewhat remote, affinities with the algae ordinarily placed in the Tetrasporales." Thus according to Smith's concept Planophila belongs to the Coccomyxaceae family and can be brought under the Tetrasporales though to the real representatives of it has but a slight affinity. Fritsch (1948) takes the opposite view and classifies Planophila in the Chlorococcales order's Chlorosphaeraceae family, thinking that due to the presence of vegetative division, Planophila is more closely allied to those reduced forms which belong to this order. In spite of this he makes the following remark (loc. cit., p. 193): "The exact position of these forms is at present difficult to establish. Chlorosphaera (which he unites with Chlorosarcina) has been regarded by many as possibly being reduced from a filamentous type, mainly because of the tendency to form short threads seen in some species. There is no reason, however, why vegetative division should not have arisen in unicellular forms, and it is not out of the question that the Chlorosphaeraceae may be primitive." The occurrence of the biflagellated swarmers would certainly lend support to this latter view. In the newest comprehensive monograph on algae (Fott, 1959) Planophila is not treated. On the basis of the above considerations I enumerated Planophila in the Coccomixaceae sensu Smith (1950). Electronmicroscopic investiga- 
tions which are currently underway may yield some other clues as to the correct place of this genus among the green algae (Sample Nos. 7, 10).

\section{Ulothrichaceae}

20. ULOTHRIX TENERRIMA Kütz. fa.

The filaments which according to all of their characteristics could be identified as U.tenerrima exhibited a peculiar type of growth: they were found coiled in the form of a close spiral (Fig. 7.). Similar coiling in a blue-green algal species: Oscillatoria articulata was observed by Gardner and he named these forms as varietas circinata. Palik (1939) also described a coiled blue-green alga: Fortiea (Leptobasis) goesingense but subsequent authors, like Hollerbach et al. (1956) pointed out that such coiling is not a useful systematic mark and is most probably due to some environmental factor. As according to my knowledge no similar observations has as yet been made on a Ulothrix species, it seemed to be interesting to call attention to the described phenomenon without attaching to it any systematic significance or trying to speculate about the nature of factors which caused it. The species occurs both in running and still water, also on cliffs moistened by the water spray. Found also in the original material without culturing (Sample No. 12).

\section{Characiaceae}

\section{HARPOCHYTRIUM HYALOTHECE Lagerh.}

The systematic position of this apochlorotic form is extremely uncertain. Originally it was classified as a fungus (Chitridiales), but later when closely resembling colored forms were found, it was transferred to the Chrysophyta and placed into the Characiopsidaceae family on the basis that its zoospores have two unequal flagellae (Pascher, 1939). According to the investigations of Korshikov (1953) the colored species of Harpochytrium belong to the Chlorophyta in the Characiaceae family representing a new genus Acrochasma. Korshikov came to this conclusion since he could not observe the presence of the second, short flagellum indicated by Pasher (loc. cit.). Unfortunately he does not treat $H$.hyalothece in his monograph thus we still do not know its correct systematic position. On the grounds of Korshikov's investigations, however, it seemed to be advisable to enumerate this species in the Chlorophyta as an apochlorotic represen- 
tative of the Characiaceae family. H.hyalothece is a typical epiphyte usually on Zygnematales, in this investigation, however, it occurred attached to small debris particles (Sample No. 6).

\section{0ocystaceae}

\section{CHLORELLA VULGARIS Beijer.}

Ubiquitous, cosmopolitan (Sample No. 2).

\section{OOC YSTIS LACUSTRIS Chod.}

In still and flowing water very common, cosmopolitan. Cf. remark of Species No. 1 (Sample No. 10).

\section{ANKISTRODESMUS FALCATUS (Corda) Ralfs.}

In still and flowing water, common, cosmopolitan. Cf. remark of Species No. 1 (Sample Nos. 9, 12).

\section{KIRCHNERIELLA LUNARIS (Kirchn.) Möb.}

Common in the plankton of still or running water, cosmopolitan. Cf. remark of Species No.1. Found also in the original material without culturing (Sample No. 12).

\section{SCENEDESMUS ABUNDANS (Kirchn.) Chod.}

Common planktonic organism but may appear as an aerophyta also on barks, in greenhouses, etc. Found also in the original material without culturing (Sample Nos. 5, 12).

\section{RHODOPHYTA}

\section{Lemaneaceae}

\section{LEMANEA TORULOSA (Roth) Ag.}

The occurrence of this Rhodophyton in the cave is surprising. It was found in great abundance on an old log and the apperance of its thallus suggested a fungus. Under microscopic examination, however, it turned out to be a red alga. The fresh water species of Lemanea inhabit rapidly flowing small streams and, though capable of tolerating some degree of pollution, need adequate aeration for their growth. 
Thus, the presence of L.torulosa on the log and its possibly heterotrophic nutrition is astonishing. Red algae were also reported from other caves (Claus, $1961 \mathrm{a}, 1961 \mathrm{~b}$ ), but there they always occurred either in the streams attached to rocks or on the rock walls, heavily sprayed by water. It was impossible to culture this species in any of the media employed, which further bespeaks a possibly complicated nutritional requirement supplied in the cave by the putrescent log (Sample No. 12a).

It must be mentioned here that Sample No. 4 contained only fungal mycelia, while No. 3 proved to be completely sterile. In Sample Nos. 8 and 11 heavy fungal growth occurred along with the algae. No attempt was made to identify any of the fungi.

The identified forms are enumerated in Table 1, and their localities within the cave are marked there.

\section{Discussion}

The algological investigations resulted in the determination of twenty-seven taxa. Although the presence of diatoms was noted in several samples they were not included in the floral list presented in this paper since they will be reported elsewhere. The distribution of the different species among the algal Divisions is as follows: Cyanophyta, 11 species, 1 form; Euglenophyta, 1 species, 1 varietas; Chrysophyta, 2 species; Chlorophyta, 10 species; Rhodophyta, 1 species. As can be seen from this enumeration, all the algal Divisions except the Pyrrhophyta and Phaeophyta are represented in these samples. It is not surprising that the representatives of these Divisions were not encountered in the samples since the greatest majority of the forms belonging to the Pyrrhophyta are euplanktonic organisms, while the Phaeophyta live in marine habitats.

In discussing the ecology of cavernicole algae the usual treatment is to get hypothetical answers for three problems: 1. Are the algae present in the caves carrying out an actively reproducing, vegetative life or are they found only in forms of resting stages, spore, etc.? This problem immediately raises the second question: 2 . If the algae, indeed, carry out normal life functions in the darkness of the caves, what energy source do they utilize for their assimilatory activities? As the presence of algae in caves by now is an established fact one has to face the third problem: 3 . How did the algae get into the speleoenvironment and, since many of the species recorded from different caves are extremely rare forms, how is one able to explain their presence in these subterranean habitats? 
Table 1. Algal Occurrences in Mammoth Cave

\begin{tabular}{|c|c|c|c|c|c|c|c|c|c|c|c|c|c|c|}
\hline \multirow{2}{*}{ Name of Organism } & \multicolumn{14}{|c|}{ Sample Number } \\
\hline & 1 & 2 & 3 & 4 & 5 & 6 & 7 & 8 & 9 & 10 & 11 & 12 & $12 \mathrm{a}$ & Total \\
\hline $\begin{array}{l}\text { Ankistrodesmus falcatus (Corda) Ralfs } \\
\text { Asterococcus superbus (Cienk.) Scherf. } \\
\text { Beggiatoa alba (Vauch.) Trev. } \\
\text { Chlorella vulgaris Beijer. } \\
\text { Chrysococcus klebsianus Pasch. } \\
\text { Chrysophyta cyst } \\
\text { Coccomixa dispar Schmidle } \\
\text { Gomontiella magyariana Claus } \\
\text { Harpochytrium hyalothece Lagerh. } \\
\text { Kirchneriella lunaris (Kirchn.) Möb. } \\
\text { Lemanea fluviatilis Ag. } \\
\text { Lyngbya pusilla (Rabenh.) Hansg. } \\
\text { fa. tenuior fa. nov. } \\
\text { Microcystis stagnalis Lemm. } \\
\text { Nostoc minutissimum Kütz. emend. Claus } \\
\text { Oscillatoria animalis Ag. } \\
\text { Oscillatoria clausiana spec. nov. } \\
\text { Oscillatoria neglecta Lemm. } \\
\text { Oscillatoria subtilissima Kütz. } \\
\text { Oocystis lacustris Chod. } \\
\text { Phacus pleuronectes (Ehr.) Duj. } \\
\quad \text { var. hyalinus Klebs } \\
\text { Phormidium cebennense Gom. } \\
\text { Phormidium subtruncatum Woronich. fa. } \\
\text { Planophila laetevirens Gerneck } \\
\text { Scenedesmus abundans (Kirchn.) Chod. } \\
\text { Tetrachloris inconstans Pasch. } \\
\text { Trachelomonas verrucosa Stokes } \\
\text { Ulothrix tenerrima Kütz. fa. }\end{array}$ & $\begin{array}{l}\times \\
\times\end{array}$ & $x$ & & & $x$ & $x$ & $x$ & $x$ & $x$ & $x$ & $x$ & $\begin{array}{l}x \\
\times \\
\times \\
\\
\times \\
\times\end{array}$ & $x$ & $\begin{array}{l}2 \\
2 \\
1 \\
1 \\
1 \\
1 \\
1 \\
1 \\
1 \\
1 \\
1 \\
1 \\
\\
1 \\
1 \\
1 \\
1 \\
1 \\
2 \\
1\end{array}$ \\
\hline Total: 27 taxa & 3 & 3 & 0 & 0 & 3 & 3 & 1 & 2 & 2 & 4 & 1 & 10 & 1 & \\
\hline
\end{tabular}


All three of these questions have been dealt with in detail by Claus (1955, 1962a, 1962 b), Palik (1960a, 1960b), and Suba (1957), and in the present study it seemed to be repetitious to enumerate all the hypotheses which were advance by them to give answers for the above mentioned three problems. But as none of the ideas put forth by the mentioned authors is completely satisfactory in answering these questions one is still faced with ambiguities in connection with the ecology of cave algae and the present study may give some further clues as to their elucidation.

Since, in most instances, previous studies dealing with the problem of assimilation of cave algae completely ruled out phototrophism, and no radiation was found in caves which could be utilized as an energy source for assimilation, one had to suppose that the algae are either chemoautotrophs or heterotrophs. Both of these suppositions, however, run into difficulties as pointed out earlier by the enumerated authors. In the Mammoth Cave many of the collections resulted in cultures containing but a few species (two or three), indicating that on relatively large areas only a few algal specimens were present. A similar observation was made by Claus (1955) in the Baradla Cave. This, however, may indicate that the algae grown in the cultures originated from a few, possibly one, parent organism which was surviving the troglobitic conditions in the form of a resting stage. Collection No. 12, which contained the most species, with largest abundances, originated from a place in the cave which got at least intermittent illumination supplied by an electric lamp. There are many visitors to the cave, thus the illumination is occasionally kept on for almost 12 hours a day, which naturally would be sufficient to supply adequate energy for the algal growth. Both in the Peace Cave and the cave of Abaliget, Claus (loc. citt.) described extensive growth of Rhodophyta occurring on rocks or in the river bed. On the other hand, in the Mammoth Cave the Lemanea species was found growing on a rotting log. Since the Audouniella species reported from the Peace Cave was floating in the river one may suppose that it was carried in to its location from somewhere else. It may well have been ripped off by the current from some kind of organic substrate. The other Audouniella species, found in the cave of Abaliget, partially also grew on logs. In spite of the contrary opinion of Claus (1961 a) the log, even in this latter case, could have served not only as a substrate, but may have been supplying adequate amounts of organic material to the alga. The fact that the thalli of the red alga were also found to grow on the walls of the cave still does not contradict the idea that it derived its food supply originally from the log through interconnections or some 
kind of other transport mechanism operating in the mucus of the species. The other reported cases, when microscopically visible algal growth was observed in confirmedly dark regions of caves are more difficult to explain by assuming heterotrophic growth. Since, however, in these latter cases, like that reported by Palik (1960b), the algal thalli were so small that chemoautotrophic assimilation may have been sufficient. The abundant growth of the red algae actually presented the biggest obstacle to the acceptance of chemosynthetic processes. If, however, heterotrophism would be proven as the operating factor in the anabolism of the Rhodophyta then chemoautotrophism could, indeed, be accepted as the energy supplying process for the scattered occurrence of the other blue-green algae.

In the Introduction attention was called to the fact that the water level of the cave's rivers vary greatly during the year. Since the inflow of water in the Mammoth Cave is a direct consequence of the rainfall of the area and the rain water flows unobstructed into the cave many of the algal occurrences could possibly be explained by supposing that they are carried into the cavern by the streams flowing through. The role of air current or the carrying in by animals of lower order is probably secondary. That the algae, or at least some of them, are originating from the surrounding surface areas would also be substantiated by the identification of several euplanktonic forms. In Table 2 such forms are compiled and attention is called to the fact that planktonic forms were reported from the other, as yet investigated, caves too. It is interesting to note, however, that none of the previous authors attributed any significance to these algae and did not try to give a satisfactory explanation for their presence. Thus, in Table 2, all the other planktonic forms reported from caves are also enumerated. It becomes clear that these forms play a considerable role in the algal floras of caves. Since, however, they occur in most instances on the walls or on the stalactites, thus being unable to float or swim freely, one may suppose that they represent forms adapted to a more or less attached or sessile life or, and this seems to be more natural, one may come to the conclusion that these forms were recently carried into the caves by water currents. They may have had their original habitat in the abundant small ponds or lakes of the Karst regions overlying the caves. Claus (loc. citt.) points out that the surface algal floras show but few species common to those occurring in the caves and, more important, he was able to demonstrate that the vegetation of two juxtapositioned caves, Baradla and Peace Caves, is basically different, thus presenting an argument against the derivation of their floras from the surface area. Still one may suppose that at 
Table 2. Planktonic forms of algae reported from different caves

\begin{tabular}{|c|c|c|c|c|c|c|c|c|}
\hline \multirow{2}{*}{ Name of Organism } & & 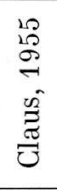 & 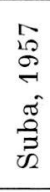 & 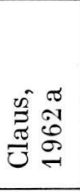 & 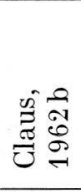 & 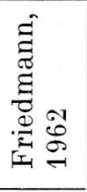 & 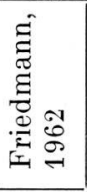 & 总 \\
\hline & 胥 & 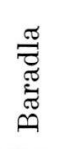 & 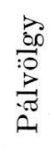 & 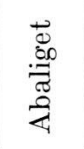 & 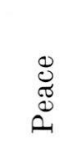 & 莡 & 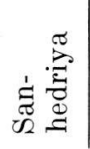 & 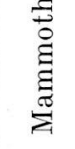 \\
\hline $\begin{array}{l}\text { Actinastrum hantzschii Lagerh. } \\
\text { Actinastrum tetaniforme Teiling } \\
\text { Ankistrodesmus falcatus (Corda) Ralfs } \\
\text { Ankistrodesmus falcatus (Corda) Ralfs var. tumidus (W.et G.S. West) } \\
\text { G. S. West } \\
\text { Ankistrodesmus faclatus (Corda) Ralfs var. mirabile W. et G. S. West } \\
\text { Ankistrodesmus lacustris (Chod.) Ostenf. } \\
\text { Ankistrodesmus setigerus (Schröd.) G. S. West } \\
\text { Aphanocapsa elachista W. et G. S. West var. planctonica G. M. Smith } \\
\text { Aphanocapsa rivularis (Carm.) Rabenh. } \\
\text { Asterococcus superbus (Cienk.) Scherf. } \\
\text { Borzia trilocularis } \text { Cohn } \\
\text { Chroococcus limneticus Lemm. var. subsalsus Lemm. } \\
\text { Chroococcus minor (Kütz.) Naeg. } \\
\text { Chroococcus minutus (Kütz.) Naeg. } \\
\text { Chroococcus turgidus (Kütz.) Naeg. } \\
\text { Chrysococcus klebsianus } \text { Pasch. } \\
\text { Coccomyxa dispar } \text { Schmidle } \\
\text { Dactylococcopsis acicularis Lemm. } \\
\text { Dactylococcopsis rhaphidioides Hansg. } \\
\text { Euglena gracilis } \text { Klebs. } \\
\text { Euglena } \text { sp. } 1 . \text { cysta }\end{array}$ & & & $\begin{array}{l}+ \\
+ \\
+ \\
+ \\
+ \\
+ \\
+\end{array}$ & $\begin{array}{l}+ \\
+ \\
+ \\
+\end{array}$ & $\begin{array}{l}+ \\
+\end{array}$ & + & + & $\begin{array}{l}+ \\
+\end{array}$ \\
\hline
\end{tabular}




\section{Euglena sp. 2. cysta}

Gloeococcus schroeterii (Chod.) Lemm.

Goniaulax sp.

Keratococcus rhaphidioides Pasch.

Kirchneriella lunaris (Kirchn.) Möb.

Lauterborniella elegantissima Schmidle

Lepocinclis steinii Lemm.

Lyngbya borgertii Lemm.

Lyngbya lagerheimii (Möb.) Gom.

Lyngbya limnetica Lemm.

Mallomonas acaroides Perty

Microcystis chroococcoidea W. et G. S. West

Microcystis flos-aquae (Wittr.) Kirchn.

Microcystis stagnalis Lemm.

Ochromonas ovalis Dofl.

Ochromonas vagans Dofl.

Oocystis crassa Wittr.var. marssonii Printz

Oocystis lacustris Chod.

Oscillatoria agardhii Gom.

Oscillatoria amphigranulata van Goor

Oscillatoria lacustris (Kleb.) Geitl.

Oscillatoria lemmermannii Wolosz.

Oscillatoria limnetica Lemm.

Oscillatoria planctonica Wolosz.

Oscillatoria redekeii van Goor

Oscillatoria woronichinii Aniss.

Phacus pleuronectes (Ehr.) Duj. var. hyalinus Klebs

Planophila laetevirens Gerneck

Scenedesmus abundans (Kirchn.) Chod.

Scenedesmus bijugatus (Turp.) Kütz.

Scenedesmus quadricauda (Turp.) Brèb. var.dispar (Brèb.) Brunn.

Synechocystis aquatilis Sauv.

Trachelomonas verrucosa Stokes

Trachelomonas sp.

Total: 55 taxa

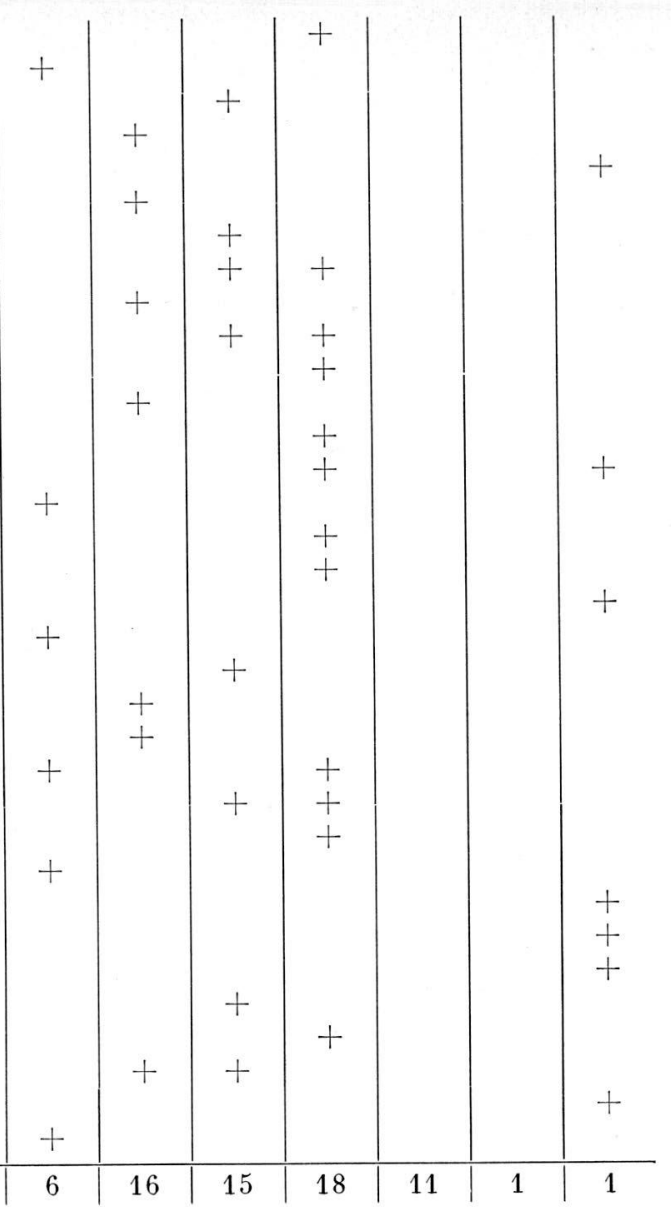


least certain members of the algal population, especially the planktonic forms, recently entered the caves from the surface.

Each of the caves investigated up to now exhibited the presence of such species which are either rare, originate from Arctic or Antarctic regions, or have to be considered endemisms (cf. many new forms described). In order to explain the presence of such forms Claus (loc.citt.) worked out the hypothesis that the algal floras of the caves originated during the time of the caves' formations and in many instances have a pre-glacial or glacial relict character. According to his opinion the caves served as areas of refugium for the surface algal population both for those forms escaping the glaciations and for those glacial species which escaped the later rise in temperature. A further support to this theory was supplied by Suba (1957) who found several thermal species in the cave of Pálvölgy. According to the geological data this cave arose as a result of the activity of thermal springs excavating the dolomite layer, thus in this case the presence of the thermophilic algae would be an indication of the fact that the algae got into the caves concurrently with the formation of the latter. One difficulty in accepting this lucrative idea is presented by the extremely wide ecological valency of most of the reported algae. No doubt can be raised as to the ubiquitous, cosmopolitan nature of most of the Cyanophyta, which usually comprise at least 50 percent of the cave algal populations. Consequently the fact that a particular blue-green alga has only been reported from Arctic or Antarctic habitats, and was rediscovered living in a cave, does not constitute a proof of the cave's flora representing a glacial type. Probably the most typical example to disprove this idea was supplied by the occurrence of Phormidium frigidum Fritsch in the Baradla Cave. This alga was originally described from Antarctica and later was found in the High Tatra, then in several rivers of the Soviet Union, in Sweden, France, and the United States, in middle European lakes, and even on the coast of Morocco. Clearly Ph.frigidum is a cosmopolitan without any special preference towards temperature. Several other Cyanophyta originally described from cold climates and later found in caves were subsequently identified from the most varied habitats. Thus the case for concluding from the presence of originally psychrophilic species to a glacial type of cave flora is weakened by the latitude of adaptability of these algae.

The numerous new species described from caves might represent endemic forms since the cave environment supplies very specialized ecological conditions. One may speculate on the species forming effect of such an environment, but this again leads to certain difficulties. It 
is generally accepted that speciation occurs due to spontaneous mutations. The sole known natural factor bringing about mutation is cosmic radiation but the investigations of Claus (1955) have shown that "the dark background" within the caves of Baradla and Peace is much less, only one-fifth of that occurring on the surface. The limestone layers apparently are effective absorbers of cosmic rays. If, however, the effect of this mutagenic factor can be excluded from the speleoenvironment then it is hard to imagine that the ecological conditions prevailing in the caves alone can bring about speciation. Therefore, the origin of the described new species has to be looked for somewhere else and they cannot easily be accepted as endemisms. Since the surface algal flora of the Earth is rather unknown, and every day results in the description of several new species, one may suppose that the "endemic forms" described from caves also occur on the surface but have as yet not been found.

In spite of the doubtful origin of the algal floras of caves their existence at least has been unquestionably proven. The sterile conditions of collection and the sterile handling during the culture of the material indicate that the algae obtained in the cultures were also present in the cave and do not represent external contaminants. Thus, one may conclude that a specific and possibly autochthonous cave algal flora exists. If such is the case, however, the algae must play a role in the food supply of the cavernicole animals regardless whether or not they are chemoautotrophs or heterotrophs. At the present time it seems that at least some of the algae occurring in the caves are chemoautotrophs and thus must be primary producers. If, however, primary producers do occur in caves the concepts about the biological food chains of the speleo-environment has to be revised. Plants representing the $\Lambda_{1}$ niveaux may produce adequate quantities of food for the consumption of the $\Lambda_{3}$ niveaux at least in areas around the lamps.

The scattered occurrences of the different algal species in the Mammoth Cave, in areas other than those which got some degree of illumination would, however, make questionable even the role of these algae in the food chain of the other organisms. Since it becomes clear from Table 1 that not a single species was found in the cave in more than three localities one may come to the conclusion that these solitarily distributed specimens are not abundant enough to serve as adequate food supply. For the same reason it is practically impossible to make any comparisons between the algal floras of the different samples representing different, more or less distinct, habitats of the cave. It seems that in spite of the microecological differences prevailing in such varied habitats as the cave walls or the cave rivers, they do 
not serve as sufficient factors to bring about the development of representative specific floras. The sole exception to this is presented by Sample No. 12, which showed both a greater diversity and abundance of algal species, however, as it was pointed out earlier, this sample originated from an area which got adequate illumination. Thus, at least in the Mammoth Cave, light indeed seems to be the limiting factor for the development of a luxuriant algal growth. On the other hand, the fact that many of the cultures contained one or only a few species also indicates that the collections may have contained only a fraction of the algae which occurred in the cave. Similar conclusions were also reached by earlier investigators who have frequently pointed out that each crack in the walls, each stalactite or stalagmite may have a different algal population. For these reasons it is obvious that our study has only a preliminary character and that much more work, especially more thorough collecting, is required in order to obtain a better understanding of the algal flora of the Mammoth Cave.

If one tries to make a comparison between the algae found in the Mammoth Cave and in the investigated European and Palestinean caves several interesting conclusions can be reached. The most striking feature of the algal population of the Mammoth Cave is the scarcity both of the number of species found and the infrequency of their encounter. As the 13 samples were collected from an approximately three kilometer stretch, one would expect a greater diversity of species than that found. From a much smaller stretch Claus reported 69 species (59 without diatoms) from the Baradla Cave (1955), 92 (76 without diatoms) from the relatively small cave of Abaliget (1960a), and 91 (87 without diatoms) from an approximately 800 meter length of the Peace Cave (1960 b), while Suba described 41 (39 without diatoms) different algae from the barely 400 meter long cave of Pálvögy (1957). No adequate explanation can be advanced at the present for this phenomenon.

Another feature peculiar to Mammoth Cave is that most of the samples contained only from 1 to 4 species. From this point of view Mammoth Cave resembles only the Baradla Cave where a similar observation was made by Claus (loc.cit.). All the other caves investigated so far produced samples containing up to 28 different species indicating that a well-developed and diversified algal flora exists in the different habitats. The reasons for this lack of algal abundance in Mammoth Cave is unclear at the present.

The third distinguishing feature of Mammoth Cave is the almost complete absence of species common to the other previously investigated caves. Considerable numbers of identical species were found among the different Hungarian caves which, in the case of the Peace 
Cave, even shed some light on the possible origin of the cave (cf. Claus, 1962 b). The lack of such species in the Mammoth Cave would indicate that the manner in which this cave became populated with algae may somewhat differ from that of the other caves. The few species common to several caves are enumerated in Table 3 . One should point out that although it has no statistical significance, and all of the commonly occurring species are more or less ubiquitous cosmopolitans, the algal flora of the Mammoth Cave can still best be compared with that of the Cave of Alibaget. It is interesting to note that not a single species was found to be common to both the American and Palestinean caves. Because of the scarcity of the available data concerning the algal population of the Mammoth Cave one cannot even speculate about the processes which might have resulted in the populating of this cave by algae.

Although the results of this investigation are far from complete, it has become clear that algae do occur in Mammoth Cave, that the cave, and thus probably other American caves, have their own distinctive algal population, differing from that found in the European caves. More investigations are needed in this area in order to bring about a better understanding of the existing algal cave floras, to solve the problem of their assimilation and to clarify their importance in the nutritional chains of the other troglobitic species.

Table 3

Species Common to Mammoth Cave and Investigated European Caves

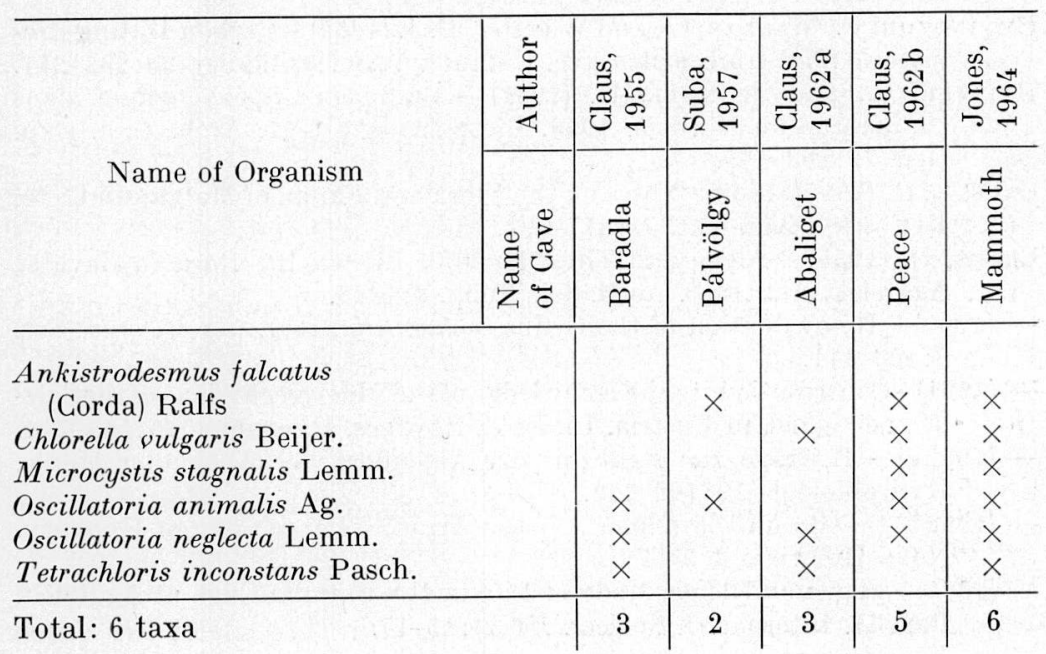




\section{SUMMARY}

Algological investigations carried out in the Mammoth Cave, Kentucky, revealed the presence of twenty-seven taxa representing all Divisions of the Algae except the Pyrrhophyta and Phaeophyta; Diatoms although observed in the samples were not dealt with in the present paper. One species, Oscillitoria clausiana spec. nov. and a form Lyngbya pusilla fa. tenuior fa. nov., both belonging to the Cyanophyta are new to science. In addition, several other rare and interesting algae were found. A comparison is made between the algal flora of the Mammoth Cave and algae found in several European caves. The ecology of the cavernicole algae is discussed.

\section{ZUSAMMENFASSUNG}

In einer algologischen Untersuchung der Mammoth-Höhle (Kentucky) wurde das Vorkommen von 27 Arten bzw. Formen festgestellt, die alle Algenklassen außer Pyrrhophyceen und Phaeophyceen repräsentieren. Die Diatomeen, deren Anwesenheit in der Probe festgestellt wurde, sind in dieser Abhandlung nicht betrachtet.

Eine Art, Oscillatoria clausiana nov. spec., und eine Form, Lyngbya pusilla fa. tenuior fa. nov., beides Cyanophyceen, werden neu beschrieben. Darüber hinaus wurden weitere seltene und interessante Algen gefunden.

Ein Vergleich wird angestellt zwischen der Algenflora der MammothHöhle und den Algen, die in verschiedenen europäischen Höhlen nachgewiesen wurden. Die Ökologie der höhlenbewohnenden Algen wird diskutiert.

\section{REFERENCES}

Barr, T. C. (1962) - The Blind Beetles of Mammoth Cave, Kentucky. Am. Midl. Nat. 68:278-284.

- (1964) - Cave Ecology. Science 144:321-322.

Benington, F., Melton, C., and Watson, P. J. (1962) - Carbon Dating Prehistoric Soot from Salts Cave, Kentucky. Am. Antiquity 28:238-241.

Bolivar, C., and Jeannel, R. (1931) - Campagne Spéléologique dans l'Amérique du Nord en 1928. Biospeleologie LVI. Arch. Zool. Exp. Gen. 71:293-499.

CALL, E. R. (1897) - Some Notes on the Flora and Fauna of Mammoth Cave, Kentucky. Am. Nat. 31:377-392.

Claus, G. (1955) - Algae and Their Mode of Life in the Baradla Cave at Aggtelek. Acta Bot. Acad. Sci. Hung. 2:1-26.

- (1960) - Re-evaluation of the Genus Gomontiella. Rev. Algol. Nouv. Ser. $5: 103-111$.

- (1961) -Contributions to the Knowledge of the Blue-green Algae of the Salzlacken-Gebiet in Austria. Internat. Rev. ges. Hydrobiol. 46:514-541.

- (1962 a) - Beiträge zur Kenntnis der Algenflora der Abaligeter Höhle. Hydrobiologia 19:192-222.

- (1962 b) - Data on the Ecology of the Algae of Peace Cave in Hungary. Nova Hedwigia 4:55-79.

- (1964) - Algae and Their Mode of Life in the Baradla Cave at Aggtelek. Part II. Internat. J. Speleol. 1(1-z):13-17. 
Friedmann, I. (1955) - Geitleria calcarea n. gen. and n. sp. A New Atmophytic Lime-incrusting Blue-green Alga. Bot. Not. 108:439-445.

- (1956) - Beiträge zur Morphologie und Formwechsel der atmophytischen Bangioidee Phragmonena sordidum Zopf. Öster. Bot. Zeitschr. 103: 613-633.

- (1961) - Chroococcidiopsis kashaii sp. n. and the Genus Chroococcidiopsis. Öster. Bot. Zeitschr. 108:354-367.

- (1962) - The Ecology of the Atmophytic Nitrate-Alga Chroococcidiopsis kashaii Friedmann. Arch. Mikrobiol. 42:42-45.

Fritsch, F. E. (1935-1945) - The Structure and Reproduction of the Algae. I.: 1-791, 1935; II.: 1-939, 1945. Univ. Press, Cambridge.

Fотт, B. (1959) - Algenkunde.: 1-482. VEB. G. Fischer, Jena.

Geitler, L. (1925) - Cyanophyceae. In: Pascher's Süßwasserflora... 12:1281. G. Fischer, Jena.

- (1932) - Cyanophyceae. In: Rabenhorst's Kryptogamenflora... 14:11196. Akad. Verlag, Leipzig.

Gernegk, R. (1907) - Zur Kenntnis der niederen Chlorophyceen. Beih. Bot. Centralbl. 21:221-290.

Heering, W. (1914) - Chlorophyceae. In: Pascher's Süßwasserflora... 6: 1-250. G. Fischer, Jena.

- (1921) - Chlorophyceae. In Pascher's Süßwasserflora... 7:1-103. G. Fischer, Jena.

Hollerbach, M. M., Kossinskaja, E. K., and Poljansky, I. V. (1953) Sinezelenije vodorosli. In Opredelitely presnovodnikh vodoroslej S.S. S.R. 2:1-199. Sovj. Nauk., Moskva.

Korsнiкоv, O. A. (1953) - Viznatshnikh presnovodnikh vodoroslej Ukrainskoj R.S.R. 5 (Protococcineae): 1-439. Adad. Nauk. Ukr., Kijev.

Lemmermann, E., Brunthaler, J., and Pascher, A. (1915) - Chlorophyceae. In: Pascher's Süßwasserflora... 5:1-250. G. Fischer, Jena.

Loвеск, A. K. (1929) - The Geology and Physics of the Mammoth Cave National Park, Kentucky. Kentucky Geol. Surv. Ser. 6 (31):327-399.

Matvienko, A. M. (1954) - Zolotistyje vodorosli. In Opredelitely presnovodnikh vodoroslej S.S.S.R. 3:1-188. Sovj. Nauk., Moskva.

PaLIK, P. (1939) - Eine interessante Blaualge aus Ungarn. Arch. Protistk. $92: 147-148$.

- (1960a) - Study into the Algal Flora of Caves. Hidrol. Közl. 40:417-422.

- $(1960 \mathrm{~b})$ - A New Blue-green Alga from the Cave Baradla near Aggtelek. Ann. Univ. Sci. Budapestiensis R. Eötvös nom. 3:275-285.

Pascher, A. (1939) - Heterokonten. In: Rabenhorst's Kryptogamenflora... 11:1-1092. Akad. Verlag, Leipzig.

Pascher, A., Schiller, J., and Migula, W. (1925) - Heterocontae, Phaeophyta, Rhodophyta, Charophyta. In: Pascher's Süßwasserflora... 11:1-206.

Popova, T. G. (1955) - Evgljenovyje vodorosli. In Opredelitely presnovodnikh vodoroslej S.S.S.R. 7:1-282. Sovj. Nauk., Moskva.

Pringsheim, E. J. (1964) - Heterotrophism and Species Concepts in Beggiatoa. Am. J. Bot. 51: 898-913.

Sмiтн, G. M. (1950) - The Fresh-water Algae of the United States.: 1-719. McGraw-Hill Co., New York, Toronto, London.

Sмгтн, P. M. (1964) - The Flint Ridge Cave System: 1957-1962. Bull. Nat. Speleol. Soc. 26:17-27. 
Starr, R. C. (1956) - Culture Collection of Algae at Indiana University. Lloydia 19:129-134.

Suba, E. (1957) - Die Algen der Pálvölgyer Höhle in Ungarn. Verhandl. Zool-Bot. Ges. Wien. 97: 97-109.

VanLandingham, S. L. (1964) - Chrysophyta Cysts from the Yakima Basalt. (Miocene) in South-Central Washington. J. Paleont. 38:729-739.

Watson, R. A., and Sмiтh, P. M. (1963) - The Mammoth Cave National Park Research Center. : 1-50. Cave Res. Found., Yellow Springs, Ohio.

\section{EXPLANATION OF PLATE 104 (1)}

Fig. 1 a: Gomontiella magyariana Claus, ventral view.

Fig. 1 b: Same as above, dorsal view.

Fig. 2: Oscillatoria clausiana spec. nov.

Fig. 3: Phormidium subtruncatum Woronich. fa.

Fig. 4: Lyngbya pusilla (Rabenh.) Hansg. fa. tenuior fa. nov.

Fig. 5: Chrysophyta cyst.

Fig. 6a: Planophila laetevirens Gerneck, mature cell.

Fig. $6 \mathrm{~b}$ : Same as above, vegetative division.

Fig. 6c: Same as above, biflagellated swarmer.

Fig. 7: Ulothrix tenerrima Kütz. fa. 


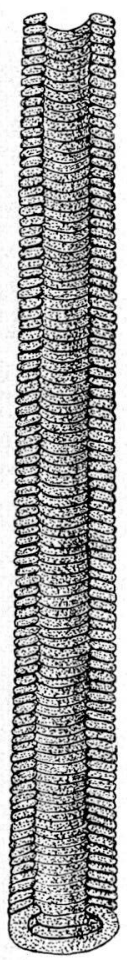

Fig. 1a

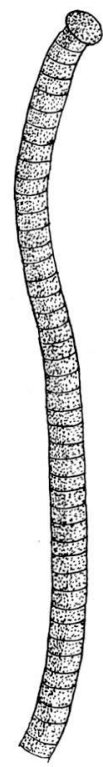

Fig. 2

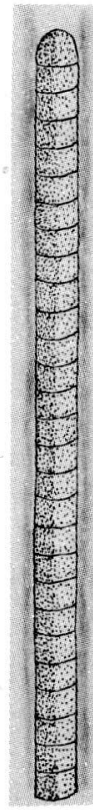

Fig. 3
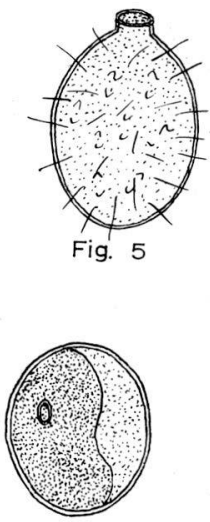

Fig. $6 a$

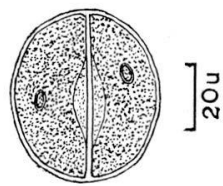

Fig. $6 \mathrm{~b}$

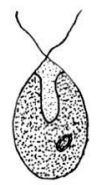

Fig. 6c
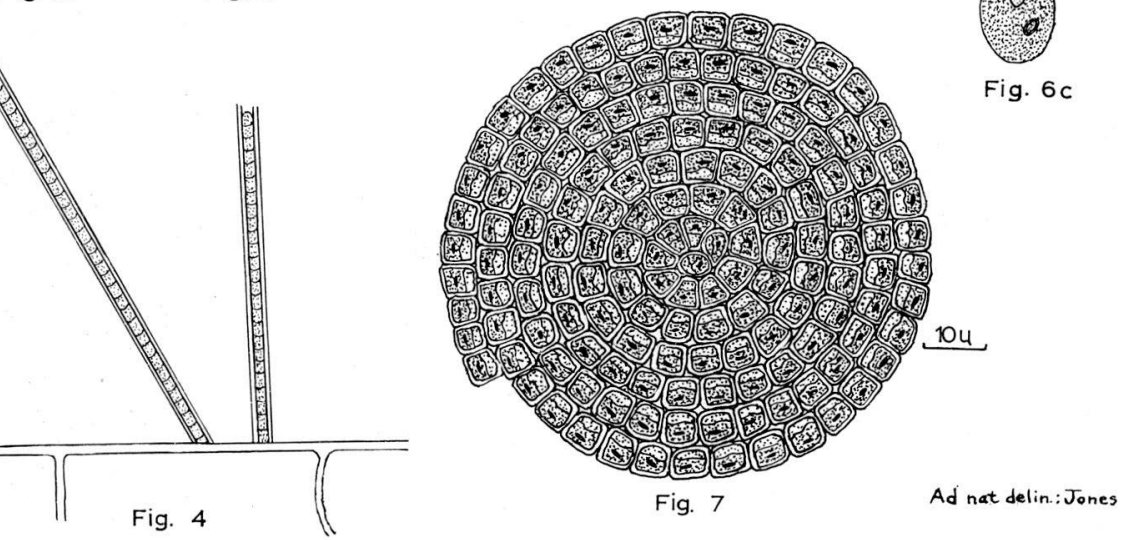